\title{
THEORETICAL AND APPLIED RESEARCH IN THE FIELD OF HIGHER GEODESY CONDUCTED IN RZESZOW
}

\author{
Roman Kadaj, Tomasz Świętoń \\ Department of Geodesy and Geotechnics, \\ Faculty of Civil and Environmental Engineering and Architecture, \\ Rzeszow University of Technology
}

\begin{abstract}
Important qualitative changes were taking place in polish geodesy in last few years. It was related to application of new techniques and technologies and to introduction of European reference frames in Poland. New reference stations network ASG-EUPOS, together with Internet services which helps in precise positioning was created. It allows to fast setting up precise hybrid networks. New, accurate satellite networks became the basis of new definitions in the field of reference systems. Simultaneously arise the need of new software, which enables to execute the geodetic works in new technical conditions. Authors had an opportunity to participate in mentioned undertakings, also under the aegis of GUGiK, by creation of methods, algorithms and necessary software tools. In this way the automatic postprocessing module (APPS) in POZGEO service, a part of ASG-EUPOS system came into being. It is an entirely polish product which works in Trimble environment. Universal software for transformation between PLETRF89, PL-ETRF2000, PULKOWO'42 reference systems as well as defined coordinate systems was created (TRANSPOL V. 2.06) and published as open product. An essential functional element of the program is the quasi-geoid model PL-geoid-2011, which has been elaborated by adjustment (calibration) of the global quasi-geoid model EGM2008 to 570 geodetic points (satellite-leveling points). Those and other studies are briefly described in this paper.
\end{abstract}

Keywords: automatic postprocessing, combined geodetic network, empirical reduction of observations, empirical transformation on a grid

\section{Introduction}

In this review article, some theoretical and applied researches in the field of higher geodesy, that were elaborated in the past years in frames of projects in line with the initiative of the Main Office of Geodesy and the Cartography (in PL: GUGiK) are 
concisely presented. The researches mentioned above was conducted by ALGORES-SOFT team in Rzeszów, on the basis of the results of statutory research carried out in the Department of Geodesy and Geotechnics at Rzeszów University of Technology, also as modified programs for commercial GeoNet system (www.geonet.net.pl). General elaborations for GUGiK are applied as official products for polish geodesy, as APPS module in POZGEO service of ASG-EUPOS system and TRANSPOL 2_06 program. The program contains e.g. quasi-geoid model PLgeoid-2011 and conversion algorithms between polish coordinates systems and reference frames. Program has been published in: www.asgeupos.pl, www.gugik.gov.pl.

Paper contains the following issues:

- Elaboration of APPS module (Automatic Postprocessing Software) for POZGEO service of polish ASG-EUPOS system (Kadaj and Świętoń, 2007, 2008a, 2008b, 2009a, 2009b, 2010; Kadaj, 2008, 2010, 2012a).

- Elaboration of algorithms for transformation between polish reference frames: PL-ETRF2000, PL-ETRF89, PULKOWO 42 and cartographic coordinates systems (PL-2000, PL-1992, 1965, 1942, 1942/86) according to polish DecreeLaw concerning National Reference Systems. Algorithms are integrated in Transpol v. 2.06 program (Kadaj and Świętoń, 2012; Kadaj, 2015).

- Elaboration of algorithms for transformation between polish height frames: PLKRON86-NH, Kronstadt60, PL-EVRF2007-NH (Amsterdam) and creation of quasi-geoid model PL-geoid-2011 as result of a calibration of global EGM2008 model on satellite and levelling networks (Kadaj and Świętoń, 2012; Kadaj, 2013, 2014).

- Elaboration of empirical methodology for observational reductions in geodetic networks (Kadaj, 2016a).

- Comparative analyses and optimizations of functional models of combined (hybrid) geodetic networks adjusted in the ellipsoidal frame (Kadaj, 2016b).

\section{The algorithm and APPS-program in POZGEO service of ASG-EUPOS system}

The program of automatic post-processing (APPS module) in POZGEO service of ASG-EUPOS system is an entirely Polish module (Kadaj and Świętoń, 2007, 2008a, 2008b, 2009a, 2009b, 2010; Kadaj, 2008, 2010, 2012a), which was integrated with Trimble services. Fig. 1 shows general structure and data flows in POZGEO service with the APPS module. Contact with the user is held on the Internet. Servers with software and databases are located in Katowice and Warsaw. Fig. 2 shows an example of geometrical structure of a sub-network for automatic post-processing. The program chose an optimal set of 6 GPS baseline vectors from 10 shortest vectors between ROVER and reference stations. 




Fig. 1. Functional structure and data flow in POZGEO Service.

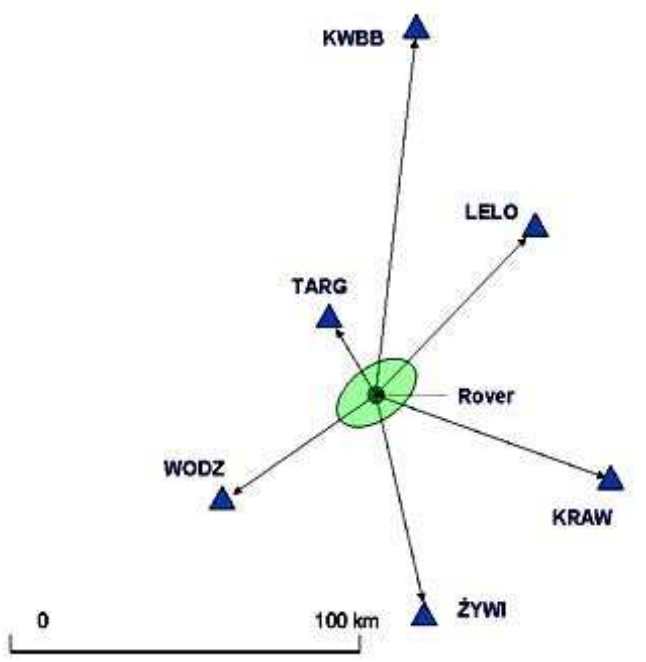

Fig. 2. A sub-network example for APPS - positioning 
For a single baseline calculations (postprocessing) in APPS, following algorithms and operations are implemented:

\section{Data preparation:}

The first stage contains the following elements:

- calculation of orbital parameters on the basis of broadcast ephemerids,

- reduction of code and phase observations with absolute antenna calibration parameters, antenna height, and tropospheric refraction (optionally two standard models are possible to be applied)

- calculation of discrete (for epochs) satellites positions $\{(X, Y, Z)\}$ and solving of SPP (Single Point Position) for two points.

\section{The analysis of phase observations and special float solution:}

a) phase - filtration for L1, L2 signals (cycle-slips rejection and defects elimination, "wide-lane" (L5), "geometry free" and "iono-free" (L3) phase combination usage).

b) float-type solution combined with iterative optimization method (Kadaj, 2012a) and final cycle-slips search (repetition of the phase-filtration).

\section{The final baseline-solution realized by two alternative methods:}

If the session-length $<1.5 \mathrm{~h}$ (optional 2.0h) then $\mathrm{DD}$ (fixed) method is applied (a). Otherwise TD (float) BETA method (b) is used. DD, TD symbols will be denoted as: double and triple phase differences.

a) DD - special fixed method - description (Kadaj, 2012a).

In the method the integer ambiguities are fixed independently for each pair of epochs $(k, k+1)(k$ is an natural index of epoch), using the "wide-lane" and "geometry free" phase combinations, which leads to the popular method denoted as "60/77". (Yang, Goad, Schaffrin,1994; applied e.g. in: Kashani, Wielgosz, GrejnerBrzezińska, 2003). The characteristic feature of the implemented algorithm is, that the optimal ambiguities are not searched in the full session. For each pair epoch (k, $\mathrm{k}+1)$ there are also the components of a free Cartesian GPS vector $[\Delta X(k), \Delta Y(k)$, $\Delta Z(k)]$ calculated. Finally, there are some optimal values $[\Delta X, \Delta Y, \Delta Z]$ of this components adjusted from the full set of epochs pairs $(k, k+1)$.

b) TD (float) - BETA method - description (Kadaj, 2008, 2010)

The method uses the triple phase differences (TD), not only for adjacent epoch, but for each pair of epochs, according to the Schreiber's schema. The triple phase differences eliminates the ambiguities, then the method leads to the special float solution. The Schreiber's schema of the used set of triple differences leads to the least squares problem with diagonal weight matrix for created pseudo-observational equations. Optionally, a robust estimation was considered:

$$
\Sigma \varphi\left(v_{i}\right)=\Sigma\left(v_{i}^{2}+c^{2}\right)^{1 / 2}=\min . \quad\left(\text { if } c \rightarrow 0 \text { then } \varphi\left(v_{i}\right) \rightarrow\left|v_{i}\right|\right)
$$

where $v_{i}$ - observational corrections, $\mathrm{i}$ - index of observation, $\mathrm{c}$ - constant value.

The TD-BETA method is effective only for long session, longer then 1.5h (optional 2.0h). Then we get results with the centimetre-level accuracy, often better than when DD-method applied. However, for shorter sessions the TD-BETA method can give worse exactness - in this case, DD-method is automatically chosen. The effect is shown symbolically on the Fig. 3 and is a result of many numerical tests executed 
using the APPS module independently by the post-processing program in GeoNet system (www.geonet.net.pl).

The final position of a ROVER - point in Cartesian geocentric system (in PLETRF2000 frame) is calculated in the adjustment process of the local network with only one unknown point and known chosen reference stations (Fig. 2). For practical applications, the Cartesian geocentric coordinates are converted to geodetic (B, L, h) and cartographic (PL-1992, PL-2000) coordinates, and also to system of normal heights (PL-KRON86-NH) with the use of quasi-geoid model PL-geoid-2011.

The APPS module will be modified in the next months, first of all by DD-special fixed algorithm extension, and by phase filtration and accuracy analysis.



Fig. 3. Method choice, depending on the session length.

3. Algorithms and parameters for transformation between polish reference frames and polish coordinates systems, which are determined in official papers concerning National Reference Systems.

\subsection{Transformation between reference frames represented by 3D or 2D geodetic networks}

Fig. 4 shows symbolically, official Polish determination of the reference frames, and cartographic coordinate systems as well as the representation of the defined reference frames and the reference networks of various class. The new PLETRF2000 reference frame (since 2012) is represented by the ASG-EUPOS stations (ca. 100) and is a Polish realization of the European Terrestrial Frame on the epoch 
2011,0. Previous reference frame, PL-ETRF89 with the new cartographic systems PL-2000, PL-1992, was primarily represented by the networks: EUREF-POL + POLREF (ca. 350 points). Into this frame and coordinates systems all geodetic numerical products have been converted from old coordinates system "1965" in reference frame PULKOWO'42. The elaboration of the transformation formulas between various reference frames and coordinate systems was a very important problem of polish geodesy (see Kadaj and Świętoń, 2012).

The transformation formulas between frames PULKOWO'42 and PL-ETRF89 have been determined and published since 2000 (e.g. Kadaj, 2001). Nowadays, transformation formulas between the last defined reference frames: PL-ETRF2000 and PL-ETRF89 are needed. The problem, depending on the specific application, was solved using two methods:

- the regular (theoretical) method, based on 7 - parameters of the (conformal) transformation.

- the empirical method, based on the interpolation grid (e.g. Świętoń, 2014).

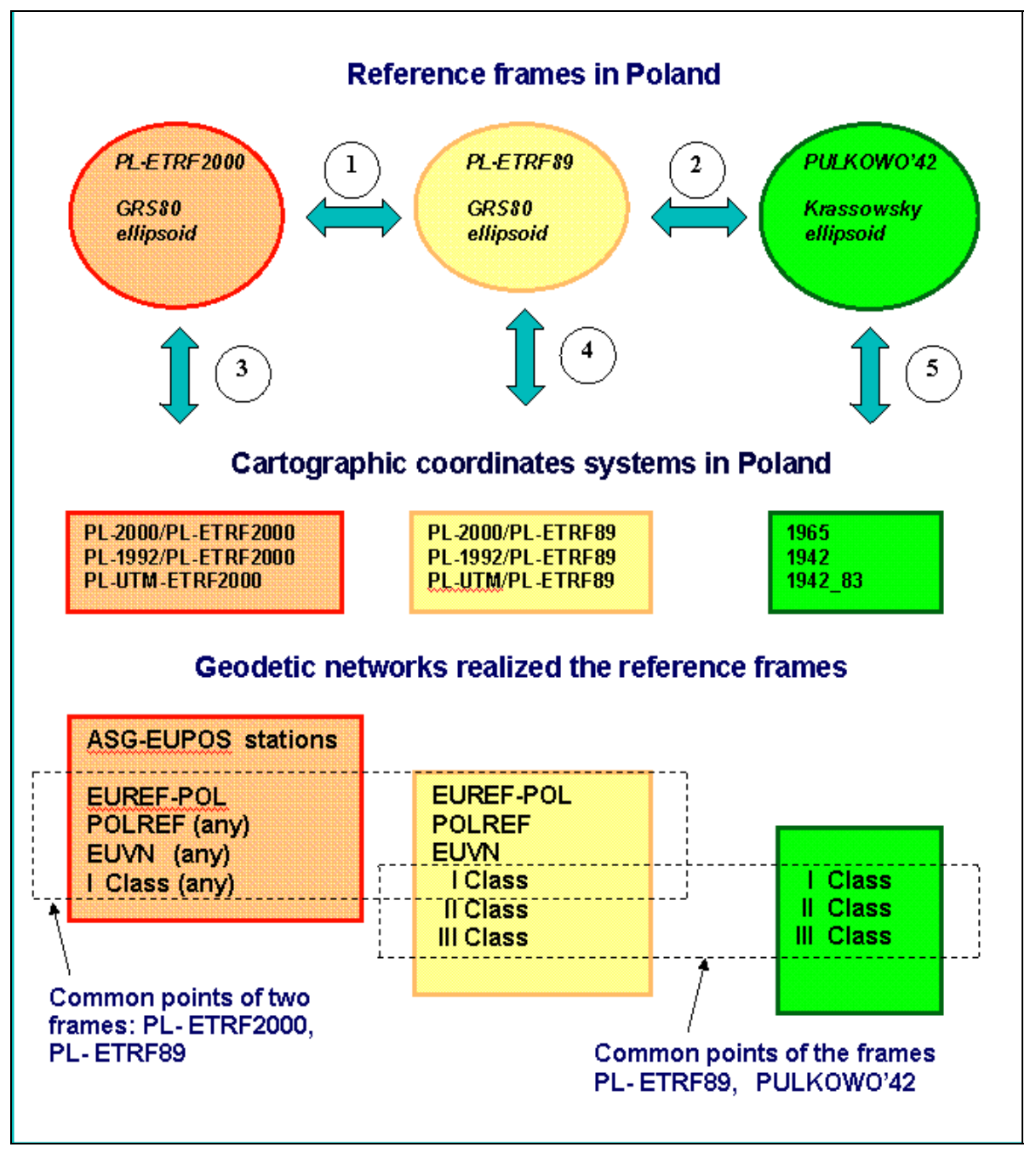

Fig. 4. Structure of reference frames with defined coordinates systems and geodetic networks representing the reference frames in Poland 
The basis of regular (theoretical) method, are the parameters of 3D conformal (7parameters) transformation. This parameters were estimated using POLREF points. At first this network was measured in years 1992-1994 and contains of about 350 points. For the estimation of the transformation parameters only 330 points from this network was used. This points were measured in years 2009-2011 together with ASG-EUPOS network and were verified as stable (see: Bosy, 2012; Jaworski et al., 2012; Liwosz T. et al., 2012). The final forms with parameters of the 3D conformal transformation are written in Table 1 (see: Kadaj and Świętoń, 2012).

Tab. 1. Procedures and transformation parameters between PL-ETRF89 and PLETRF2000, estimated on the basis of 330 points of POLREF network

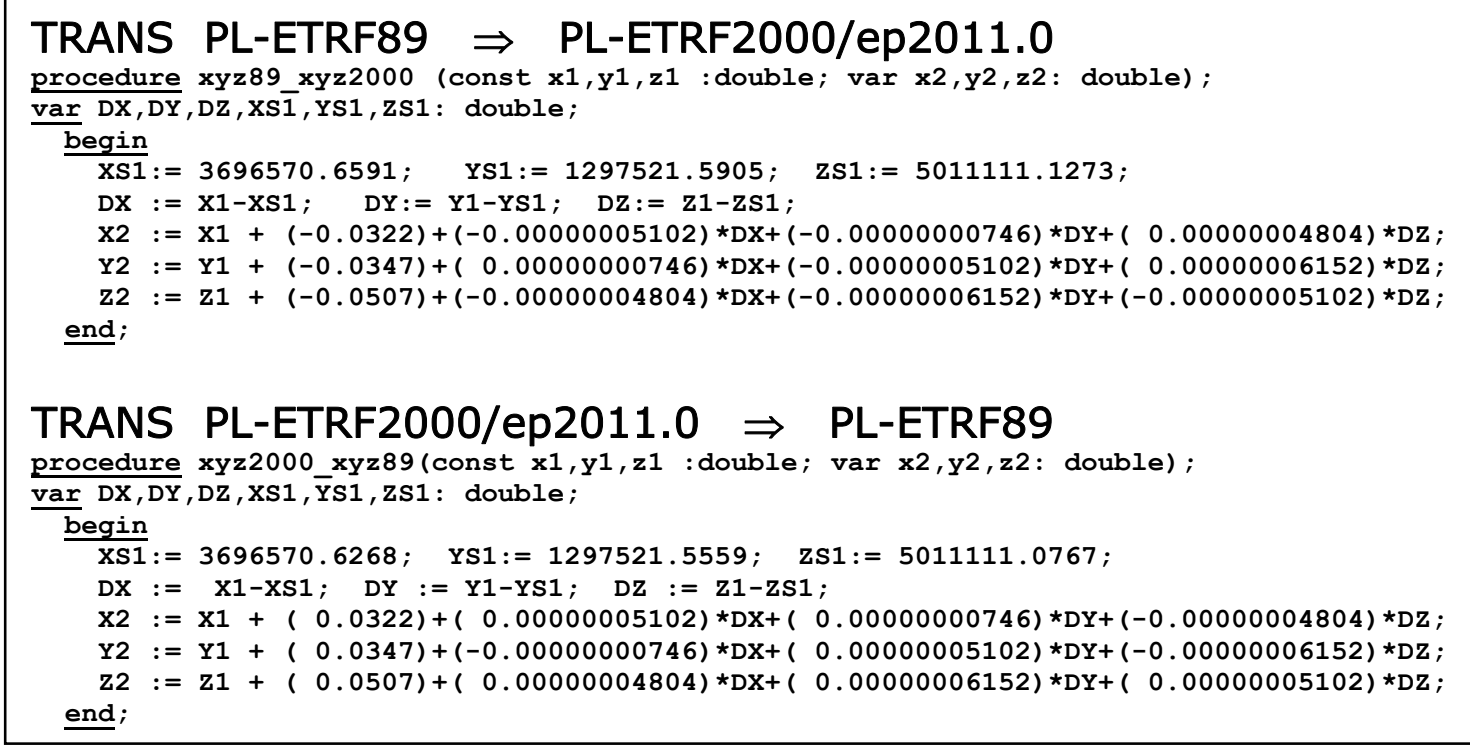

The standard deviations for 330 points are: $s X=0.011 \mathrm{~m}, s Y=0.008 \mathrm{~m}, \mathrm{sZ}=0.013 \mathrm{~m}$ The largest absolutely residuum value for 330 points is about $6.5 \mathrm{~cm}$.

Analysing the differences between two frames PL-ETRF2000 - PL-ETRF89 in the horizontal (in a mapping) (dx, dy) and vertical (dh) directions on Polish area, we get the following intervals of such deviations:

$\mathrm{dx}:<-0.44 \mathrm{~m}, 0.029 \mathrm{~m}>$, dy: $<-0.051 \mathrm{~m}, 0.020 \mathrm{~m}>$, dh: $<-0.128 \mathrm{~m},-0.005 \mathrm{~m}>$

The largest values of shifts relate to ellipsoidal heights.

The parameters and procedures of the regular 7 - parameters transformation between frames: PULKOWO'42 and PL-ETRF89 have been published by the GUGiK (Kadaj, 2001).

The empirical algorithms are constructed independently for two pairs of reference frames (as 2D transformation):

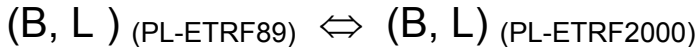



The algorithms based on an interpolation grid constructed for area of Poland with the cell size $0.01^{\circ} \times 0.01^{\circ}$, in the range of geodetic coordinates: from $49^{\circ}$ to $55^{\circ}$ for the latitude and from $14^{\circ}$ to $24,2^{\circ}$ for longitude (Fig. 5). For the each node $(\mathrm{i}, \mathrm{j}$ ) of the basis grid, with known coordinates $\left(B_{i j}{ }^{\text {PL-ETRF89) }}, \mathrm{L}_{\mathrm{ij}}{ }^{(\text {(PL-ETRF89) }}{ }^{2}\right.$ ), two numerical features are determined: $\Delta \mathrm{B}_{\mathrm{ij}}, \Delta \mathrm{L}_{\mathrm{ij}}$ (e.g.: Świętoń, 2014): 


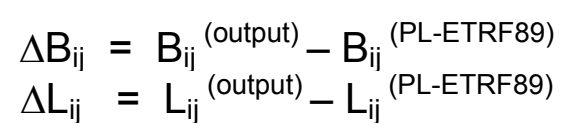

where "output" denotes the frames: PL-ETRF2000 or PULKOWO'42. The values $\Delta B_{i j}, \Delta L_{i j}$ for each node of the basis grid, for a pair of frames are interpolated on the basis of geodetic network points. In case of the frames: PL-ETRF89 and PLETRF2000 (2) the geodetic networks used for the grid interpolation are: EUREF-POL + POLREF + EUVN + the old network of the I class (ca. 6500 points, for which only geodetic coordinates $B$, L exists) (see Fig. 4). In the 2D transformation (for geodetic coordinates $B, L)$ the above networks are characterized as homogenous.

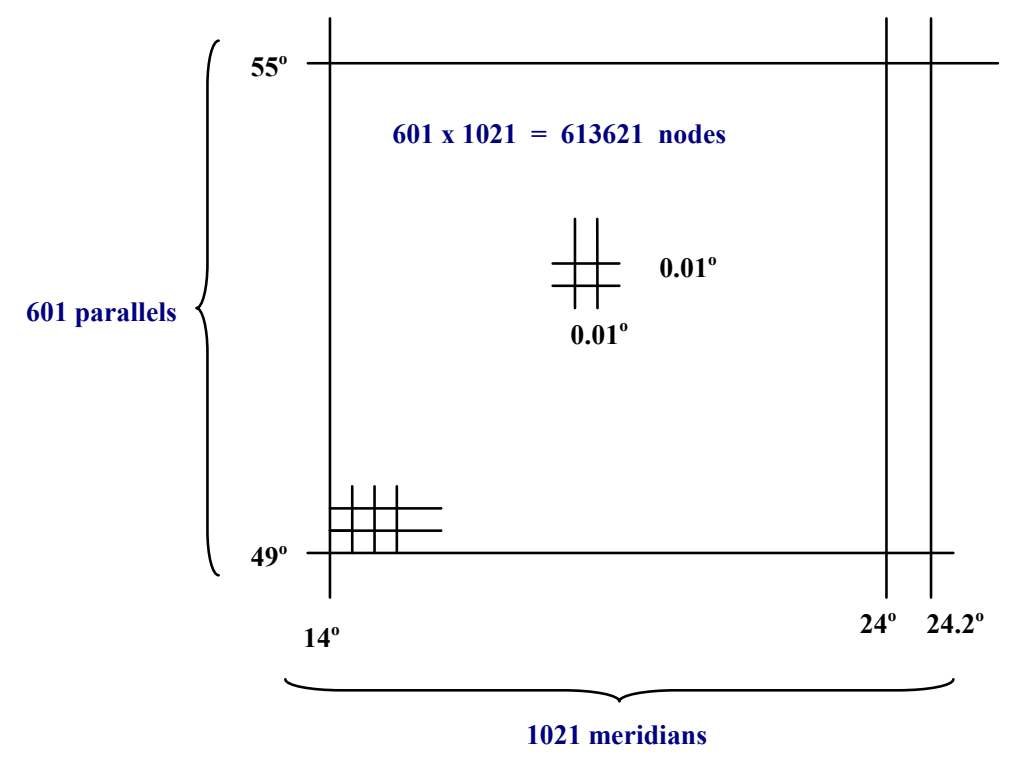

Fig. 5. The structure of the basis net for an interpolation grid creation

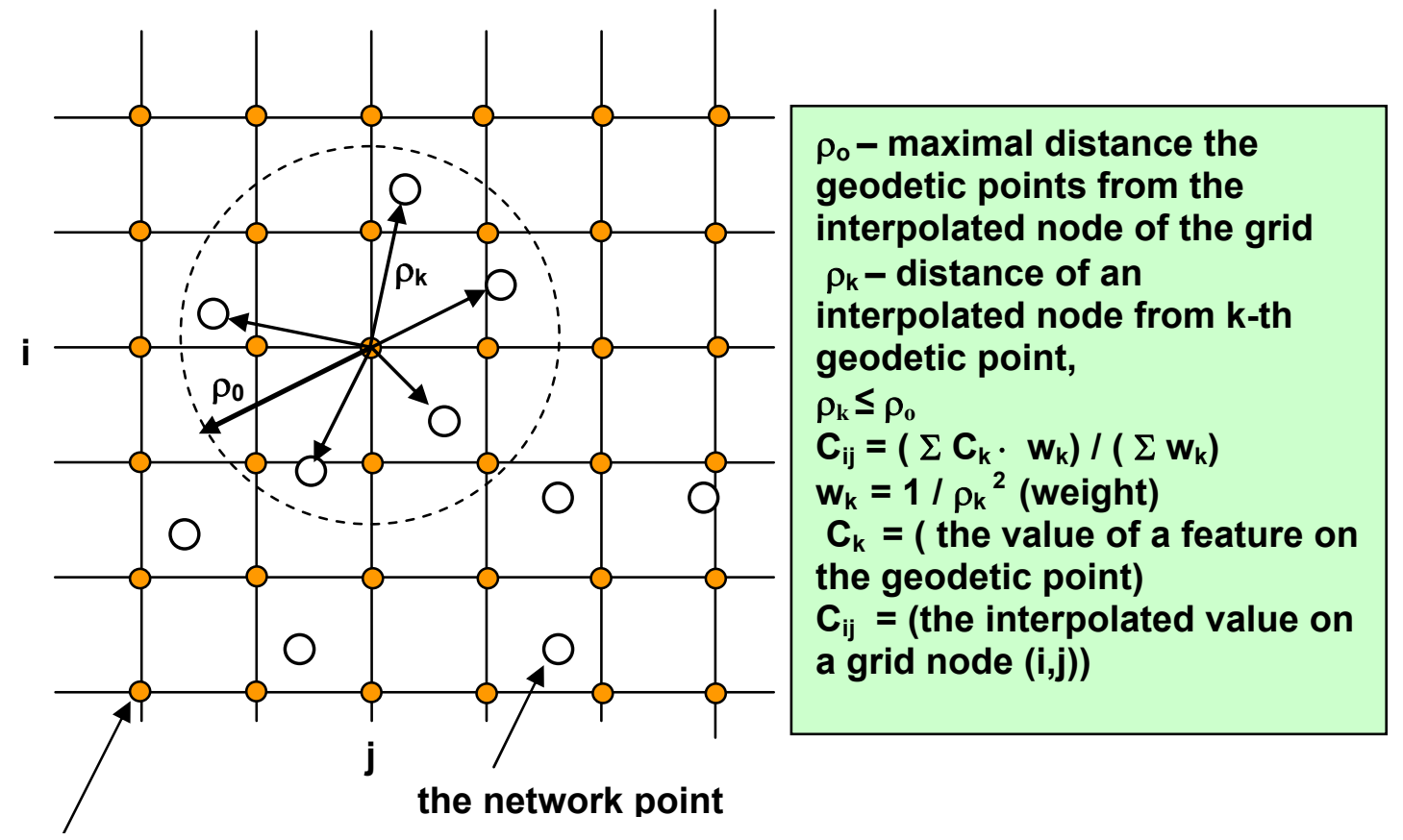

the node of the basis grid

Fig. 6. Determining the features of interpolation grid on the basis of reference network 
The interpolation of the values $\Delta B, \Delta L$ for a real point $(B, L)$ is realized in an elementary cell (quadrate field) including the data point, using the very known bilinear interpolation.

However, a special method should be used for inverse empirical transformation $(B, L)_{\text {input }} \Rightarrow(B, L)_{\text {PL-ETRF89 }}$ ("input" denotes PL-ETRF2000 or PULKOWO'42), while the input data point is not coming from the PL-ETRF89 frame, in which is the interpolation grid determined. The each node of the elementary quadrate will be displaced with its features $\Delta \mathrm{B}, \Delta \mathrm{L}$, what creates the new irregular elementary field, as in the Fig. 7. There are also other methods of inverse empirical transformation like: simplified method and iterative method to see in details in (Świętoń 2014).



Fig. 7. The illustration for an inverse interpolation (Świętoń, 2014)

In the field 1' - 2' - 3' - 4' (for example in PULKOWO'42 frame), which the knots features (increments of geodetic coordinates as displacements to the reference frame PL-ETRF89) have the algebraic sign opposite in relation to the original grid in PL-ETRF89 frame. The interpolation formula (displacements of a point $P$ to some position $\mathrm{P}^{\prime}$ ) is

$$
\begin{aligned}
& d B_{P^{-} P^{\prime}}=-\left(d B_{1} \cdot q_{1}+d B_{2} \cdot q_{2}+d B_{3} \cdot q_{3}+d B_{4} \cdot q_{4}\right) \\
& d L_{p^{\prime} p^{\prime}}=-\left(d_{1} \cdot q_{1}+d L_{2} \cdot q_{2}+d L_{3} \cdot q_{3}+d_{4} \cdot q_{4}\right)
\end{aligned}
$$

where $q_{1}, q_{2}, q_{3}, q_{4}$ are the weights fulfilling the condition $q 1+q 2+q 3+q 4=1$,

$$
q_{i}=w_{i} / w, w_{i}=1 / d_{i} \quad(i=1,2,3,4), w=w_{1}+w_{2}+w_{3}+w_{4}
$$

$d_{1}, d_{2}, d_{3}, d_{4}$ - distances of point $P$ from the points 1', 2', 3', $4^{\prime}$, expressed in lengths of arcs of ellipsoid. The assumed means of weighting have the purpose, the result nearer to a linear interpolation.

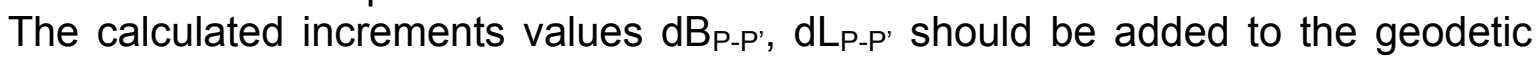
coordinates of the point in the input frame (PULKOWO'42 or PL-ETRF2000):

$$
(B, L)_{\text {PL-ETRF89 }}=\left(B, L_{\text {INPUT }}+\left(d_{P^{-} P^{\prime}}, d_{P^{-} P^{\prime}}\right)\right.
$$

(in sense of vectors addition). 


\subsection{Empirical transformation between heights reference frames}

Similarly to the empirical transformation between geodetic coordinates $(B, L)$, the same type transformation has been elaborated between Polish heights reference frame PL-KRON86-NH, newly defined heights frame PL-EVRF2007-NH (Amsterdam) and existing only in GUGiK height frame called KRON2006 (Kronstadt 2006), proposed by Gajderowicz, 2006.

The frames are represented by 15999 height points of first class. The statistic of height differences shows Table 2.

Tab. 2. Statistics of the differences between heights reference frames represented by 15999 height points of the 1-class network

\begin{tabular}{|l|c|c|}
\hline & $\mathbf{d H}=\mathbf{H}($ EVRF $)-\mathbf{H}(\mathbf{2 0 0 6})$ & $\mathbf{d H}=\mathbf{H}(\mathbf{2 0 0 6})-\mathbf{H}(\mathbf{8 6})$ \\
\hline the average value & $0.17084 \mathrm{~m}$ & $-0.00495 \mathrm{~m}$ \\
\hline minimal value & $0.15359 \mathrm{~m}$ & $-0.042 \mathrm{~m}$ \\
\hline maximal value & $0.18734 \mathrm{~m}$ & $0.057 \mathrm{~m}$ \\
\hline
\end{tabular}

Comment: the symbols $\mathrm{H}(\mathrm{EVRF}), \mathrm{H}(2006), \mathrm{H}(86)$ denote the heights in the corresponding height reference frame: PL-EVRF2007-NH, KRON2006, PL-KRON86-NH

Taking into account the average values we can assume the following general relationships:

$$
\begin{aligned}
& H(2006)=H(86)-0.00495+\mathrm{dH} 1(B, L) \\
& H(E V R F)=H(K 2006)+0.17084+d H 2(B, L)
\end{aligned}
$$

where $\mathrm{dH} 1(\mathrm{~B}, \mathrm{~L}), \mathrm{dH} 2(\mathrm{~B}, \mathrm{~L})$ as absolute minimal local (depended on the position) heights correction are interpolated on the basis on interpolation grid (for example the Fig. 8 shows graphically the distribution of differences between KRON2006 and PLEVRF2007-NH). The basis grid is the same as for the 2D transformation (see Fig. 5) and analogically to the principle shown on the Fig. 6 it determined features for all network nodes.

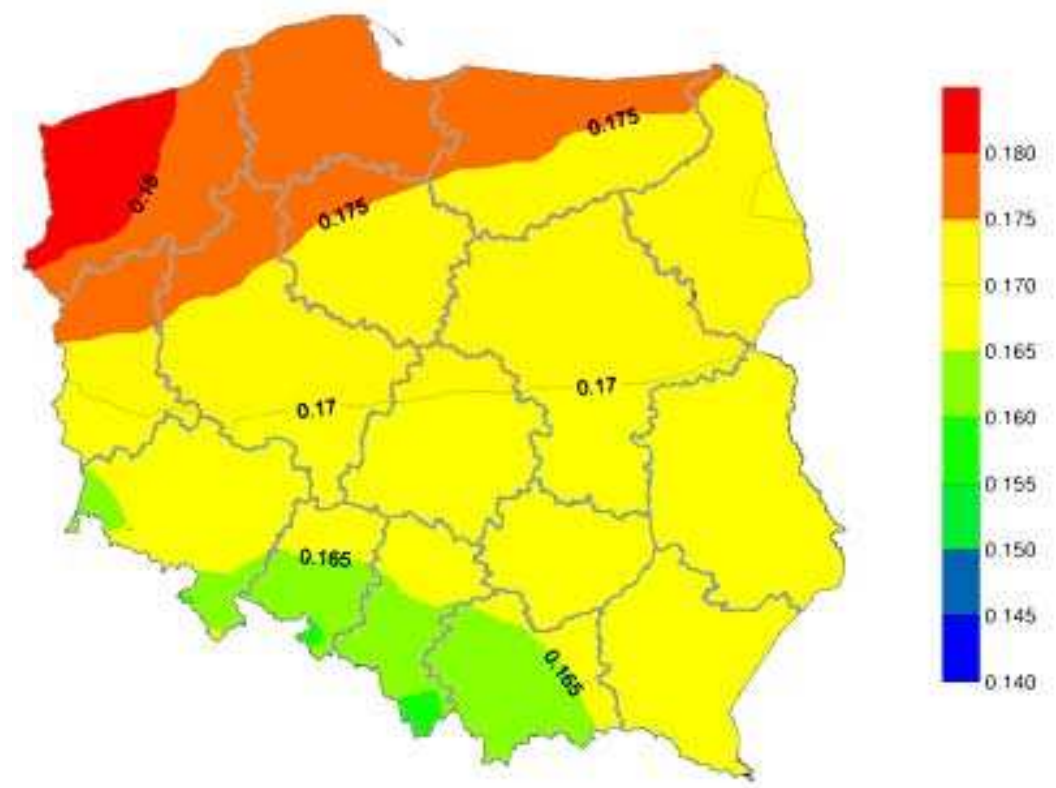

Fig. 8. Height differences between reference frames KRON2006 and PL-EVRF2007-NH 


\section{Quasi-geoid model PL-geoid-2011 as calibrated on the satellite - leveling points the global EGM2008 model}

The quasi-geoid determined by the global geopotential EGM2008 model (Pavlis et al., 2008), which includes the harmonics of degree and range 2190, has been calibrated to local polish reference frames, represented by the satellite and leveling points, creating the polish quasi-geoid model PL-geoid-2011 (Fig. 9)

Analyzing the results of past measurement campaign (2009-2011) (see: Bosy, 2012; Jaworski et al., 2012; Liwosz T. et al., 2012), integrating the ASG-EUPOS stations with the existed geodetic networks, we can select 570 points, which can be a basis for quasi-geoid calibration. The sub-networks were:

a) the ASG-EUPOS reference stations and its eccentricities - 213 points,

b) the EUVN leveling points -40 points,

c) the EUREF-POL + POLREF points- 317 points.

For all points are measured the ellipsoidal $(h)$ and normal $(\mathrm{H})$ heights. The ellipsoidal heights with geodetic coordinates $(B, L, h)$ are determined in the reference frame PL-ETRF2000, and the normal height - in the frame PL-KRON86-NH

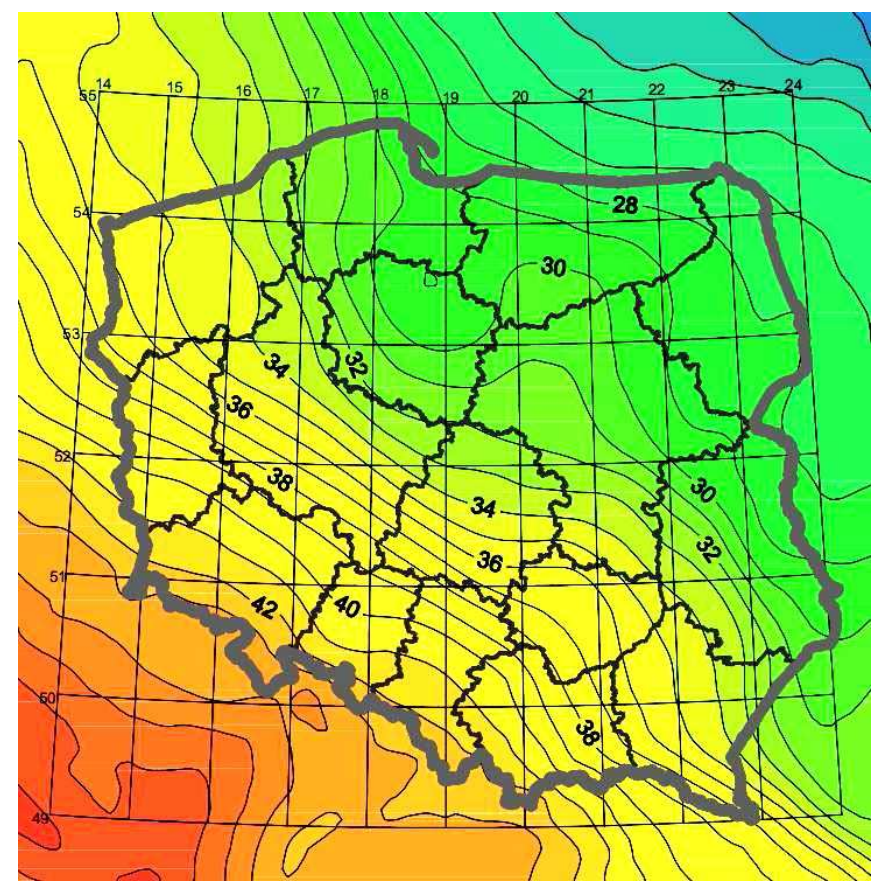

Fig. 9. Isolines of height anomalies (in meters) for the quasi-geoid model PL-geoid-2011

The differences

$$
\zeta_{\text {emp }}=\mathrm{h}_{\text {PL-ETRF2000 }}-\mathrm{H}_{\mathrm{PL}-\mathrm{KRON86-NH}}
$$

are the empirical heights anomalies calculated in geodetic points, and

$$
\zeta_{\mathrm{EGM} 2008}=\mathrm{g}(B, \mathrm{~L})
$$

the EGM2008 model of heights anomalies, where $g$ denotes an interpolation function determined on the discrete model (grid) of the quasi-geoid. The differences

$$
\delta \zeta(\mathrm{k})=\zeta_{\mathrm{EGM} 2008}(\mathrm{k})-\zeta_{\mathrm{emp}}(\mathrm{k})
$$

$$
k=1,2, \ldots, 570 \quad(k-\text { help index of geodetic point })
$$

have the statistic shown in column (1) of the table 3 (before transformation) 
The average value in column (1) can be treated as a systematic vertical displacement between model (EGM2008) and empirical quasi-geoid. There are few methods of mutual matching (calibration) of the quasi-geoid model to empirical data points as well as an empirical model (see e.g. in Łyszkowicz, 2012).

More general, if not universal, approach is based on the use of three-dimensional (7-parameters) conformal transformation. The transformation will be realized on the sets of Cartesian coordinates. For the set of 570 reference points we convert the geodetic coordinates (the points projected on the quasi-geoid surface) into the Cartesian coordinates in the corresponding reference frames:

$$
\begin{aligned}
& \left\{\left(\mathrm{B}, \mathrm{L}, \zeta_{\mathrm{EGM} 2008}\right)\right\} \Rightarrow\left\{(\mathrm{X}, \mathrm{Y}, \mathrm{Z})_{\mathrm{EGM} 2008}\right\}=\underline{\boldsymbol{X}} \\
& \{(\mathrm{B}, \mathrm{L}, \zeta \text { PL-ETRF2000 })\} \Rightarrow\left\{(\mathrm{X}, \mathrm{Y}, \mathrm{Z})_{\text {PL-ETRF2000 }}\right\}=\underline{\boldsymbol{Y}}
\end{aligned}
$$

On the basis of such determined two sets of coordinates of 570 points, the task of $3 \mathrm{D}$ transformation with estimation of 7 transformation parameters is realized:

$$
\text { 3D transformation: } \underline{\boldsymbol{X}} \Rightarrow \underline{\boldsymbol{Y}} \text { (with } 7 \text { - parameters estimation) }
$$

Tab. 3. Statistics of deviations for 570 geodetic points between:

(1) original EGM2008 heights anomalies and empiric height anomalies,

\begin{tabular}{|c|c|c|c|c|}
\hline $\begin{array}{l}\text { Name and } \\
\text { notation of a } \\
\text { parameter }\end{array}$ & $\begin{array}{c}\text { Before } \\
\text { transformation } \\
\text { (original data) } \\
\text { in [m] } \\
\text { (1) }\end{array}$ & $\begin{array}{l}\text { After vertical } \\
\text { displacements } \\
\text { in [m] } \\
\text { (2) }\end{array}$ & $\begin{array}{c}\text { after 3D } \\
\text { transformation } \\
\text { in [m] } \\
\text { (3) }\end{array}$ & Comment \\
\hline $\begin{array}{c}\text { average value } \\
\delta \zeta\end{array}$ & 0.020 & 0.000 & 0.000 & \\
\hline $\begin{array}{c}\text { standard } \\
\text { deviation } \\
\delta \zeta_{\text {st_dev }}\end{array}$ & 0.033 & 0.026 & 0.023 & \\
\hline $\begin{array}{c}\text { minimal value } \\
\delta \zeta_{\min }\end{array}$ & -0.081 & -0.101 & -0.087 & POLREF 501 \\
\hline $\begin{array}{c}\text { maximal value } \\
\delta \zeta_{\max }\end{array}$ & 0.100 & 0.080 & 0.059 & POLREF 402 \\
\hline
\end{tabular}

(2) optimal displaced EGM2008 height anomalies and empiric height anomalies,

(3) 3D transformed EGM2008 height anomalies and empiric height anomalies

The transformation parameters were estimated, according to the least squares method (for numerical elaboration was used the program TRANS_3D in the GeoNet system, www.geonet.net.pl). The obtained residues are characterized by the standard deviations in Cartesian coordinates:

$$
S x=0.0138, \quad S y=0.0049, \quad S z=0.0181
$$

The residues converted into the vertical deviations (between transformed EGM2008 and empirical heights anomalies) are written in Table 3, Column 3. In Column 2 for comparison there is a similar statistic of deviations in case of such transformation where only a vertical displacement is a non zero parameter.

On the basis of obtained parameters, the transformation of all nodes (Fig. 5) of interpolation grid (EGM2008 grid-model) can be realized. The complete conversions have the following stages: 
$\left\{\left(\mathrm{B}_{\mathrm{ij}}, \mathrm{L}_{\mathrm{ij}}, \zeta_{\mathrm{ij}}\right)_{\text {EGM2008 }}\right\} \Rightarrow\left\{\left(\mathrm{X}_{\mathrm{ij}}, \mathrm{Y}_{\mathrm{i}}, \mathrm{Z}_{\mathrm{ij}}\right)_{\text {EGM2008 }}\right\} \Rightarrow\left\{\left(\mathrm{X}_{\mathrm{ij}}, \mathrm{Y}_{\mathrm{ij}}, \mathrm{Z}_{\mathrm{ij}}\right)_{\text {PL-ETRF2000 }}\right\}\left\{\left\{\left(\mathrm{B}_{\mathrm{ij}}, \mathrm{L}_{\mathrm{ij}}, \zeta_{\mathrm{jij}}\right)_{\text {PL-ETRF2000 }}\right\}\right.$

(a)

(b)

(c)

(for all nodes of the interpolation grid: $i=0,1, \ldots, 600 ; j=0,1,2, \ldots, 1020$ )

(a): standard conversion of geodetic to Cartesian geocentric coordinates,

(b): transformation between two Cartesian systems according to known, transformation parameters (in addition, the local Hausbrand's posttransformational corrections are calculated)

(c): standard inverse transformation between Cartesian geocentric and geodetic coordinates

The local Hausbrand's corrections are interpolated on basis of geodetic points and used as weights square reciprocal of lengths between interpolated node and reference point. This method of quasi-geoid correction was criticized in several works (e.g. Olczak et al., 2014) because the distribution of Hausbrand's corrections is stronger in close neighborhood of points. It would be better to find more smooth final surface. It is possible to get such result by changing the weight function.

The above algorithm of quasi-geoid model is additionally modified, in the area of Tatry mountains, by using the special geodynamic polygon with 17 geodetic points. The modification depended on the fact, that the heights anomalies of the local nodes of transformed grid-model has been corrected taking into account the empirical anomalies of (only) additional geodetic points. The details can be found in program description (Kadaj and Świętoń, 2012).

Qualitative opinions and comparisons of EGM2008 model with various gravimetric models are to be already found in many publications, e.g. Hirth, 2011; Kryński, KlochGłówka,2009; Trojanowicz, 2009 ; Łyszkowicz, 2009. It is suggested, that the global model EGM2008 (with harmonics of high degree and rank, $n=m=2189$ ), similarly to the previous model EGM96 $(n=m=360)$, should be the basis to creation of a more exact local model based on accessible gravimetric data as well as precise numeric model of topographic surface, using the known algorithms "remove - restore". However, results of such operations do not show the essential improvements of internal exactitude of the model EGM2008. Probably it is the result of the fact, that construction of global model includes already polish gravimetric data.

However, the most important is elimination of systematic error, what is a result of differences among the empirical anomalies of heights, defined by Polish reference frames: PL-ETRF2000, PL-KRON86-NH and the anomalies resulting from the quasigeoid of the global model EGM2008 (as mathematical model of Earth was assumed probably WGS-84 model). These systematic errors can be eliminated (a geometrical matching the global model to the Polish reference frames) using the transformation algorithms with special local corrects.

\section{Empirical methodology of observational reductions in geodetic networks based on approximated points coordinates (Kadaj, 2016a)}

A geodetic network, in general, can be a set of different kinds of observations or pseudo-observations (for example, obtained by conversion of the GNSS vectors), which, through appropriate analytical compounds, including reference conditions, stochastic models and an adjustment principle, define the position of points in a conventional frame of coordinates. In specific cases it may be, for instance, geodetic (ellipsoidal) coordinate system (B, $L, h)$, Cartesian geocentric coordinates system (X, 
$\mathrm{Y}, \mathrm{Z})$ or Cartesian system $(\mathrm{x}, \mathrm{y})$ defined on a cartographic mapping. Direct observations which create a geodetic network come from the physical measurement space, different to the defined mathematical space, not only in terms of geometry, but also in terms of distortion under the influence of physical fields of the Earth, such as gravity field or atmospheric refraction. This is the universal knowledge in geodesy - see e.g. in Czarnecki, 1994. It appears therefore the problem of observational reductions.

In a conventional approach of this issue, measurements (observations) are subject to many kinds of observational reductions, for instance, a measured slant distance is reduced to horizontal position and then to the ellipsoid (reduction due to the ellipsoidal height) and finally put on the model of cartographic mapping. In the proposed empirical methodology of observational reductions, a direct (one-step) conversion of observation measures between two spaces can be realized. For this purpose, the approximate coordinates of points are used as they allow to obtain (approximate) independent observations measures in two spaces. The approximated coordinates should be correspond between two spaces (reference frames) by known transformation formulas. Based on the difference of calculated measures in both spaces, an empirical reduction as a correction of original observation measures is finally obtained.

The empirical methods of reduction were defined earlier only for cartographic mapping (see: Kadaj, 2001; Leick, 2004). In the new publication (Kadaj, 2016a) it was elaborated for various kinds of reduction of observation in geodetic network, but it was assumed, that the approximate coordinates of network points as well as the formulas of transformation between used frames (systems) are known.

Let $\Theta_{\mid}$be an elementary observation (e.g. a distance, an angle) in a measured space of geodetic network. We will reduce the observation to a measure $\Theta_{\|}$in the mathematical space where an adjustment and calculation of the network should be carried out. For this purpose, we need the quantity $\delta \Theta_{1-I I}$ as a reduction of an observation value between two spaces (in here named symbolically: I, II), $\Theta_{\|}=\Theta_{l}+$ $\delta \Theta_{|-| I}$. The reduction $\delta \Theta_{|-| \mid}$can be calculated using classic explicit form, in general, as the sum of any components: $\delta \Theta_{|-| I}{ }^{\text {(class) }}=\delta_{1}+\delta_{2}+\ldots \cong \delta \Theta_{|-| I}$. The proposed empirical methodology leads to the direct approximation of a full quantity $\delta \Theta_{\text {I-II }}$ with use of approximate coordinates of network points corresponding in both spaces. Empirical reduction approximates corresponding theoretical quantity $\delta \Theta_{|-| I}{ }^{(\mathrm{emp})} \cong \delta \Theta_{|-| I}$ and it is particularly defined as follows.

Let $\mathbf{X}^{(0)}$ be the vector containing coordinates of points representing the approximate geometric model of a given observation in a network. For example, if the observation is a slant distance, the vector $\mathbf{X}^{(0)}$ includes approximate coordinates of two points in any three-dimensional space. It may be for example a geocentric Cartesian or a topocentric system. The measure $\Theta_{l}{ }^{(0)}$ of a geometric network element, corresponding to the approximate coordinates, as a model of observation $\Theta_{\text {l }}$ in the measurement space, is expressed by a certain (known a priori) function $f_{l}$ :

$$
\Theta_{l}{ }^{(0)}=f_{l}\left(\mathbf{X}^{(0)} ; c_{1}, c_{2}, \ldots\right)
$$

where $c_{1}, c_{2}, \ldots$ parameters representing physical parameters of measurement space relative to an adopted coordinate system (e.g. local components of vertical deviations). The counterpart of the vector $\boldsymbol{X}^{(0)}$ in the mathematical space, such as a mapping plane, is a vector $\mathbf{x}^{(0)}$ obtained by a known a priori transformation (mapping) function F: 


$$
\mathbf{x}^{(0)}=\mathbf{F}\left(\mathbf{X}^{(0)}\right)
$$

Now, the measure of the corresponding geometric elements in the defined mathematical space is denoted as $\Theta_{\|}{ }^{(0)}$, using a known function $\mathrm{f}_{1 \mid}$ :

$\Theta_{\|}{ }^{(0)}=f_{\|}\left(x^{(0)}\right)$

Designating $\delta \Theta_{|-| \mid}{ }^{(0)}=\Theta_{\|}{ }^{(0)}-\Theta_{\mid}{ }^{(0)}$ we define the empirical reduction in two cases:

$$
\delta \Theta_{|-| \mid}{ }^{(e m p)}= \begin{cases}\delta \Theta_{I-||}{ }^{(0)} & \text { for azimuths, angles and directions } \\ \left(\delta \Theta_{I-||}{ }^{(0)} / \Theta_{\mid}{ }^{(0)}\right) \cdot \Theta_{\mid} & \text {for distances }\end{cases}
$$

where $\Theta_{\mid}$(without upper index) is an initial observation measure and $\Theta_{\mid}{ }^{(0)}$ corresponding measure computed with approximated point coordinates. Why has the form (19) differed cases? In case of angles (azimuths, directions) the quantity $\delta \Theta_{\mid-I 1}(0)$ is a relative measure (e.g. in radian, if $\alpha=s / r=\operatorname{arc} /$ radius the differential is $\delta \alpha=$ $\delta s / r)$, however in case of distances, the analogue relative measure will be $\delta \Theta_{|-|}{ }^{(0)} / \Theta_{\mid}{ }^{(0)}$. Yet, significant inequality between variants in (19) can be observed in case of short distances and big errors of approximated coordinates. In turn, in case of long distances and bounded errors of coordinates, the difference between variants in(19) should be, in principle, numerically not significant, especially if we assume that the approximate coordinates of the network points are successively improved in the nonlinear iterative process of network computation. For the nonlinear adjustment problem of geodetic networks is usually the Gauss - Newton (e.g. Deutsch, 1965) iterative method implemented.

\section{Adjustment algorithms for combined (hybrid) geodetic networks (Kadaj, 2016b)}

The adjustment problem of the so-called combined (hybrid, integrated) network, created with GNSS vectors and terrestrial observations has been the subject of many theoretical and applied works, since the 1970's (e.g. Krakiwsky and Thomson, 1974; Thomson 1976; Groten, 1977; Gajderowicz 1979, 1981; Adam et al., 1982; Welsch and Oswald, 1984; Baeumker, 1984; Świątek, 1986, 1988) when, for satellite positioning, Doppler observations were used. Currently in the GNSS era, the combined network adjustment is considered in various mathematical spaces: in the Cartesian geocentric system (see. e.g. Hofmann-Wellenhof et al., 2008), on a reference ellipsoid (e.g. Kadaj, 1997, 1998, 2007; Leick, 2006) and on a mapping plane (Strauss and Walter, 1993; Daxinger and Stirling, 1995; Strehle, 1996; Gajderowicz, 1997; Gargula, 2010). For practical reasons, it often takes a geodetic coordinate system associated with the reference ellipsoid. In this case, the Cartesian GNSS vectors are converted, for example, into geodesic parameters (azimuth and length) on the ellipsoid, but the simple form of converted pseudo-observations are the direct differences of the geodetic coordinates (Fig. 10). Unfortunately, the obtained measures may be essentially distorted by a systematic error resulting from an error of the position of the GNSS vector, before its projection on the ellipsoid surface. In the paper (Kadaj, 2016b) has been presented an analysis of the impact of this error on the determined measures of geometric ellipsoid elements, including the differences of geodetic coordinates or geodesic parameters. 
Assuming that the adjustment of a combined network on the ellipsoid shows that the optimal functional approach in relation to the satellite observation, is to create the observational equations directly for the original GNSS Cartesian vector components, writing them directly as a function of the geodetic coordinates. In numerical applications, we use the linearized forms (see final formulas (26)) of observational equations with explicitly specified coefficients. While retaining the original character of the Cartesian vector, avoid any systematic errors that may occur in the conversion of the original GNSS vectors to ellipsoid elements, for example the vector of the geodesic parameters. The problem was theoretically developed and numerically tested (Kadaj, 2016b).
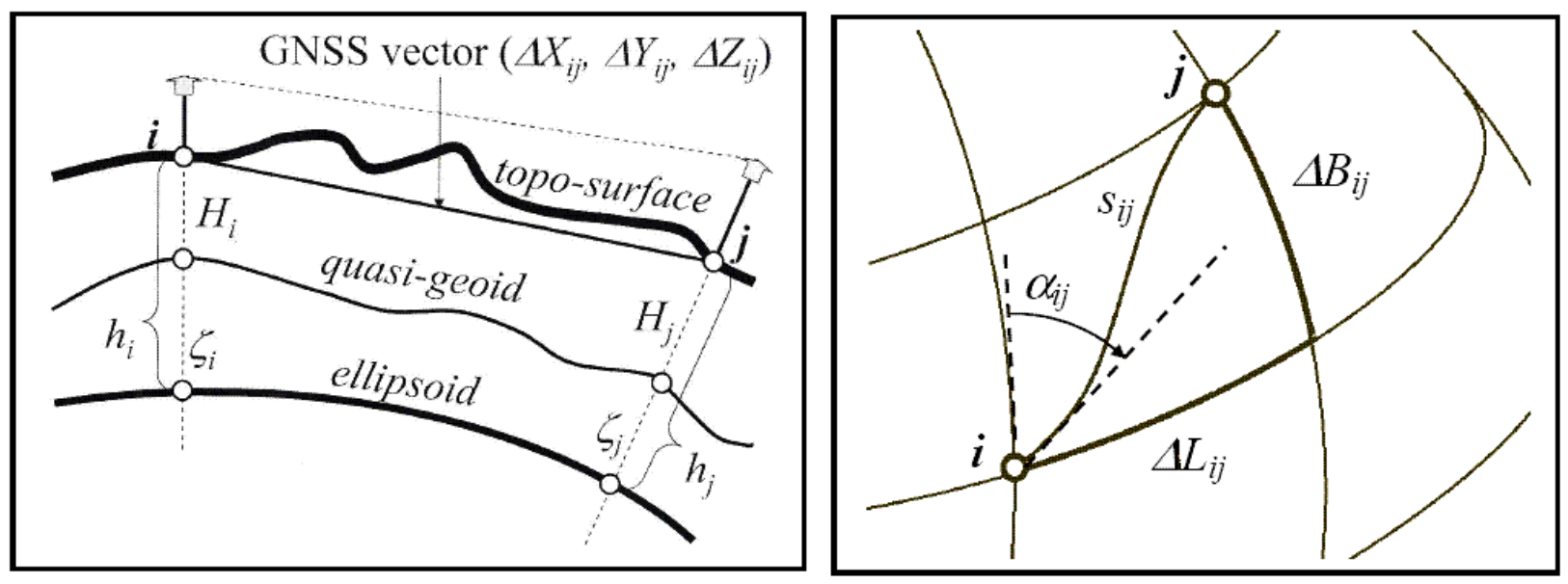

Fig. 10. Conversion of GNSS Cartesian vector into pseudo-observations as geometric elements in ellipsoidal frame

The linearized observational equation for the original 3D Cartesian GNSS vector $\Delta \boldsymbol{R}_{\mathrm{ij}}=\left[\Delta \mathrm{X}_{\mathrm{ij}}, \Delta \mathrm{Y}_{\mathrm{ij}}, \Delta \mathrm{Z}_{\mathrm{ij}}\right]^{\top}$ (i, j - points indices; ${ }^{\top}$ - transposition of the matrix) on the geocentric ellipsoid (assuming the preferred functional model) has the following matrix form:

$$
\begin{aligned}
v_{i j}=U_{j} \cdot C_{j} \cdot d E_{j}-U_{i} \cdot C_{i} \cdot d E_{i}-w_{i j}= \\
=U_{j} \cdot C_{j} \cdot \underline{C}_{j}^{-1} \cdot d e_{j}-U_{i} \cdot C_{i} \cdot \underline{C}_{i}{ }^{-1} \cdot d e_{i}-w_{i j},
\end{aligned}
$$

where (we omit the point indices)

$\mathbf{C}=\operatorname{diag}\left[\left(R_{M}+h\right),\left(R_{N}+h\right) \cdot \cos (B), 1\right]$
$\underline{\mathbf{C}}=\operatorname{diag}\left[R_{M}, \quad R_{N} \cdot \cos (B), 1\right]$

(diag - the symbol of a diagonal matrix), where $R_{M}, R_{N}$ main radii of curvature,

$$
R_{M}=a \cdot\left(1-e^{2}\right) /\left[1-e^{2} \cdot \sin ^{2}(B)\right]^{3 / 2} ; \quad R_{N}=a /\left[1-e^{2} \cdot \sin ^{2}(B)\right]^{1 / 2},
$$

$(B, L, h)$ are the geodetic coordinates ( $h$ - ellipsoidal height),

$$
\mathbf{U}=\left[\begin{array}{ccc}
-\sin (B) \cdot \cos (L) & -\sin (L) & \cos (B) \cdot \cos (L) \\
-\sin (B) \cdot \sin (L) & \cos (L) & \cos (B) \cdot \sin (L) \\
\cos (B) & 0 & \sin (B)
\end{array}\right]
$$




$$
d E=[d B, d L, d h]^{\top},
$$

- vector of unknown correction to approximate geodetic coordinates,

$$
\text { de }=[\mathrm{db}, \mathrm{dl}, \mathrm{dh}]^{\top},
$$

- correspond to $\mathrm{dE}$, vector of the small ellipsoid arc in longitude and latitude and the ellipsoidal height difference as in (25), according to dependence

$$
\begin{aligned}
& \mathbf{d E}=\underline{\mathbf{c}}^{-1} \cdot \mathbf{d e}, \\
& \mathbf{v}=\left[\mathrm{v}^{(\mathrm{X})}, \mathrm{v}^{(\mathrm{Y})}, \mathrm{v}^{(\mathrm{Z})}\right]^{\top}
\end{aligned}
$$

- vector of residues of observational equations (corrections of observations) and finally,

$$
\begin{aligned}
\mathbf{w}_{i j} & =\left[\Delta \mathrm{X}_{\mathrm{ij}}-\left(\mathrm{X}_{\mathrm{j}}^{(0)}-\mathrm{X}_{\mathrm{i}}^{(0)}\right), \quad \Delta \mathrm{Y}_{\mathrm{ij}}-\left(\mathrm{Y}_{\mathrm{j}}^{(0)}-\mathrm{Y}_{\mathrm{i}}^{(0)}\right), \Delta \mathrm{Z}_{\mathrm{ij}}-\left(\mathrm{Z}_{\mathrm{j}}^{(0)}-\mathrm{Z}_{\mathrm{i}}^{(0)}\right)\right]^{\top}= \\
& =\Delta \mathbf{R}_{\mathrm{ij}}-\left(\mathbf{R}_{\mathrm{j}}^{(0)}-\mathbf{R}_{\mathrm{i}}^{(0)}\right)
\end{aligned}
$$

is the free component, in which: $\Delta X_{i j}, \Delta Y_{i j}, \Delta Z_{i j}$ - elementary observations as components of the GNSS vector $\left.\Delta \boldsymbol{R}_{\mathrm{ij}}, \quad \mathbf{R}_{\mathrm{k}}{ }^{(0)}=\left[\mathrm{X}_{\mathrm{k}}{ }^{(0)}, Y_{\mathrm{k}}{ }^{(0)}, Z_{\mathrm{k}}{ }^{(0)}\right)\right]^{\top}(\mathrm{k}=\mathrm{i}, \mathrm{j})$ - vectors of approximated coordinates.

The development to a scalar form equations for three components of GNSS vector will be:

$$
\begin{aligned}
& v_{i j}^{(X)}= \\
& +\sin \left(B_{i}\right) \cdot \cos \left(L_{i}\right) \cdot\left(R_{M}{ }^{(i)}+h_{i}\right) \cdot d B_{i}+\sin \left(L_{i}\right) \cdot \cos \left(B_{i}\right) \cdot\left(R_{N}{ }^{(i)}+h_{i}\right) \cdot d L_{i} \\
& -\cos \left(\mathrm{L}_{\mathrm{i}}\right) \cdot \cos \left(\mathrm{B}_{\mathrm{i}}\right) \cdot \mathrm{dh}_{\mathrm{i}} \\
& -\sin \left(B_{j}\right) \cdot \cos \left(L_{j}\right) \cdot\left(R_{M}{ }^{(j)}+h_{j}\right) \cdot d B_{j}-\sin \left(L_{j}\right) \cdot \cos \left(B_{j}\right) \cdot\left(R_{N}{ }^{(j)}+h_{j}\right) \cdot d L_{j} \\
& +\cos \left(\mathrm{L}_{\mathrm{j}}\right) \cdot \cos \left(\mathrm{B}_{\mathrm{j}}\right) \cdot \mathrm{dh}_{\mathrm{j}} \\
& -\left[\Delta X_{i j}-\left(X_{j}^{(0)}-X_{i}^{(0)}\right)\right]= \\
& =+\sin \left(B_{i}\right) \cdot \cos \left(L_{i}\right) \cdot \mu_{i} \cdot d b_{i}+\sin \left(L_{i}\right) \cdot v_{i} \cdot d l_{i}-\cos \left(L_{i}\right) \cdot \cos \left(B_{i}\right) \cdot d h_{i}+ \\
& -\sin \left(B_{j}\right) \cdot \cos \left(L_{j}\right) \cdot \mu_{j} \cdot d b_{j}-\sin \left(L_{j}\right) \cdot v_{j} \cdot d l_{j}+\cos \left(L_{j}\right) \cdot \cos \left(B_{j}\right) \cdot d h_{j}+ \\
& -\left[\Delta X_{i j}-\left(X_{j}^{(0)}-X_{i}^{(0)}\right)\right] \text {, } \\
& v_{i j}^{(Y)}= \\
& +\sin \left(B_{i}\right) \cdot \sin \left(L_{i}\right) \cdot\left(R_{M}^{(i)}+h_{i}\right) \cdot d B_{i}-\cos \left(L_{i}\right) \cdot \cos \left(B_{i}\right) \cdot\left(R_{N}{ }^{(i)}+h_{i}\right) \cdot d L_{i} \\
& -\sin \left(L_{i}\right) \cdot \cos \left(B_{i}\right) \cdot d h_{i} \\
& -\sin \left(B_{j}\right) \cdot \sin \left(L_{j}\right) \cdot\left(R_{M}^{(j)}+h_{j}\right) \cdot d B_{j}+\cos \left(L_{j}\right) \cdot \cos \left(B_{j}\right) \cdot\left(R_{N}{ }^{(j)}+h_{j}\right) \cdot d L_{j} \\
& +\sin \left(L_{j}\right) \cdot \cos \left(B_{j}\right) \cdot d h_{j} \\
& -\left[\Delta Y_{i j}-\left(Y_{j}^{(0)}-Y_{i}^{(0)}\right)\right]= \\
& =+\sin \left(B_{i}\right) \cdot \sin \left(L_{i}\right) \cdot \mu_{i} \cdot d b_{i}-\cos \left(L_{i}\right) \cdot v_{i} \cdot d l_{i}-\sin \left(L_{i}\right) \cdot \cos \left(B_{i}\right) \cdot d h_{i}+ \\
& -\sin \left(B_{j}\right) \cdot \sin \left(L_{j}\right) \cdot \mu_{j} \cdot d b_{j}+\cos \left(L_{j}\right) \cdot v_{j} \cdot d l_{j}+\sin \left(L_{j}\right) \cdot \cos \left(B_{j}\right) \cdot d h_{j}+ \\
& -\left[\Delta Y_{i j}-\left(Y_{j}^{(0)}-Y_{i}^{(0)}\right)\right] \text {, }
\end{aligned}
$$




$$
\begin{aligned}
& v_{i j}{ }^{(Z)}= \\
& \quad-\cos \left(B_{i}\right) \cdot\left(R_{M}^{(i)}+h_{i}\right) \cdot d B_{i}-0 \cdot d L_{i}-\sin \left(B_{i}\right) \cdot d h_{i}+ \\
& \quad+\cos \left(B_{j}\right) \cdot\left(R_{M}{ }^{(j)}+h_{j}\right) \cdot d B_{j}+0 \cdot d L_{j}+\sin \left(B_{j}\right) \cdot d h_{j}+ \\
& \quad-\left[\Delta Z_{i j}-\left(Z_{j}^{(0)}-Z_{i}^{(0)}\right)\right]= \\
& =-\cos \left(B_{i}\right) \cdot \mu_{i} \cdot d b_{i}-0 \cdot d l_{i}-\sin \left(B_{i}\right) \cdot d h_{i}+ \\
& \quad+\cos \left(B_{j}\right) \cdot \mu_{j} \cdot d b_{j}+0 \cdot d_{j}+\sin \left(B_{j}\right) \cdot d h_{j}+ \\
& \quad-\left[\Delta Z_{i j}-\left(Z_{j}^{(0)}-Z_{i}^{(0)}\right)\right], \\
& \text { where } \\
& \mu_{k}=1+h_{k} / R_{M}{ }^{(k)}, \quad v_{k}=1+h_{k} / R_{N}{ }^{(k)} \text { for } k=i, j
\end{aligned}
$$

and the main radii of curvature $R_{M}, R_{N}$ are defined in the formula (23). Of course, if $h_{k} \rightarrow 0$ then $\mu_{k} \rightarrow 1$ and $v_{k} \rightarrow 1$.

The equations presented above are implemented and optionally used in the new version of the program for the combined network adjustment in geodetic system GeoNet (www.geonet.net.pl)

\section{Conclusions and remarks}

The works presented here in the review form are applied with success in various fields of Polish geodesy.

The APPS module has been functioning in the ASG-EUPOS system since 2007 (supported also by EU) and has been already modified several times. Accuracy of the positioning depends of duration time of observational session and it is possible to achieve sub-centimeter. In the coming months, a new modification, optimizing some stages of the automatic post-processing in the precision aspect of the automatic positioning, will be applied.

The transformation procedures between Polish coordinates systems and reference frames, as well the numerical model of the quasi-geoid PL-geoid-2011 with the usage of interpolation functions are implemented in TRANSPOL v. 2.06 program, which is officially used in geodetic and cartographic works. The program can be found at: www.asgeupos.pl and www.gugik.gov.pl .

Special issues, concerning the empirical methods for observational reductions and functional modeling of combined geodetic network has been successfully tested and applied in commercial geodetic system GeoNet (www.geonet.net.pl).

\section{Acknowledgements}

The article has been elaborated under the statutory research "Optimization of engineering measurements for civil engineering needs" in Department of Geodesy and Geotechnics at Rzeszów University of Technology, No U-544/DS, 2014-2015, at the invitation of Professor Marcin Barlik - chief editor of "Reports on Geodesy and Geoinformatics" as parts of the jubilee celebrations. The authors would like to thank Prof. Barlik for the invitation.

\section{References}

Adam J., Halmos F., Varga M. (1982). On the concepts of combination of Doppler Satellite and Terrestrial Geodetic Networks. Acta Geodaet., Geophys. et Montanist. Acad. Sci. Hung. Vol. 17(2). 
Baeumker M. (1984). Zur dreidimensionalen Ausgleichung von terrestrischen und Satellitenbeobachtungen. Wiss. Arbeiten der Fachrichtung Verm. d. Universität Hannover, 130.

Bosy J. (2012). Wyniki weryfikacji wyników integracji podstawowej osnowy geodezyjnej na obszarze kraju ze stacjami referencyjnymi systemu ASG-EUPOS. Wrocław, 30 listopada 2011r. Raport dla GUGiK - Warszawa 2012

Czarnecki K. (1994). Present Geodesy in outline. In Polish: Geodezja współczesna w zarysie. Wydawnictwo Wiedza i Życie, ISBN 83-86805-67-6. Warszawa 1994.

Daxinger W., Stirling R. (1995): Kombinierte Ausgleichung von terrestrischen und GPS - Messungen. Österreichische Zeitschrift für Vermessung und Geoinformation, 83, 48-55.

Deutsch, R. (1965). Estimation Theory. Prentice-Hall, Inc. Englewood Cliffs, N.J.

Gajderowicz, I. (1979). Łączne wyrównanie sieci dopplerowskich i naziemnych. Z.N. ART w Olsztynie. Geodezja i Urządzenia Rolne, 8.

Gajderowicz, I. (1981). A theoretical basis for simultaneous adjustment of Doppler and terrestrial networks using a satellite reference ellipsoid. Artificial Satellites, 16(1).

Gajderowicz, I. (1997). Combination of classical observations with two-dimensional GPS vectors. Olsztyn University of Agriculture \& Technology. Institute of Geodesy.

Gajderowicz I. (2006). „Wykonanie wyrównania osnowy wysokościowej I klasy i przygotowanie danych niwelacyjnych dla podkomisji EUREF". Sprawozdanie z wykonania prac określonych w umowie nr Gl-251-601-2796/2005 z dnia 04 listopada 2005roku. GUGiK, 2 pażdziernika 2006 r.

Gargula T. (2010). GPS vector Network adjustment on the projection plane of local coordinate system. Polska Akademia Nauk, Oddział w Krakowie, Komisja Technicznej Infrastruktury Wsi. Nr 6/2010, s. 133-144

Groten, E. (1977). Combination of geometrical satellite with terrestrial data. In (Eds. Halmos F. and Samogyi J.): Optimization of design and computation of control networks - International Symposium in Sopron, 4-10 July, 1977). Akademiai Kiado, Budapest, 95-104.

Hirt C., (2011). Assessment of EGM2008 over Germany using accurate quasi-geoid heights from vertical deflections, GCG05 and GPS/ levelling. Zeitschrift für Geodäsie, Geoinformation und Landmanagement (zfv) 136(3): 138-149.

Hofmann-Wellenhof B., Lichtenegger H., Wasle E. (2008). GNSS Global Navigation Satellite Systems. Springer-Verlag Wien.

Jaworski L. i in.(2012). Zintegrowanie podstawowej osnowy geodezyjnej na obszarze Polski ze stacjami referencyjnymi systemu ASG-EUPOS ETAP IV. Opracowanie i wyrównanie obserwacji GNSS. Raport CBK dla GUGiK, Warszawa, lipiec - 2012 [ Pomiary wykonane przez Konsorcjum: OPGK sp. z o.o. w Lublinie Sp. z o.o. (lider), CBK-Warszawa - wykonanie prac w etapie IV, PPGK S.A.- Warszawa, PPG Sp. z o. o. -Warszawa, OPGK w Łodzi Sp. z o.o., PMG Sp z o.o., Katowice]

Kadaj R. (1997). Adjustment of a GPS vector network and transformation to the Krassowsky or GRS80 ellipsoid mapping system. In Polish: Wyrównanie sieci wektorowej GPS $i$ jej transformacja do układu odwzorowawczego elipsoidy Krasowskiego lub GRS-80 w programach systemu GEONET. Seminarium Komitetu Geodezji PAN: Zastosowanie technik kosmicznych w geodezji i geodynamice. Kraków 22-23 września 1997.

Kadaj R. (1998). Models, methods and computation algorithms of kinematic network in geodetic deformations measurements. In Polish: Modele, metody i algorytmy 
obliczeniowe sieci kinematycznych $w$ geodezyjnych pomiarach przemieszczeń $i$ odkształceń obiektów. Wydawnictwa AR w Krakowie, 1988, ISBN 83-86524-37-5.

Kadaj, R (2001). Formuły odwzorowawcze i parametry układów współrzędnych. Wyd. GUGiK Warszawa 2001, WT G-1.10, ISBN-83-239-1473-7.

Kadaj R.(2007). Sieci wektorowe GPS z obserwacjami klasycznymi w aspekcie modernizacji państwowych osnów geodezyjnych. Mat. II ogólnopolskiej Konf. N-T „Kartografia numeryczna i informatyka geodezyjna”, Rzeszów - Polańczyk Solina, 27-29.09.2007, ISBN 978-83-7199-460-9, s. 171-179.

Kadaj R. (2008). New algorithms of GPS post-processing for multiple baseline models and analogies to classic geodetic networks. Geodesy and Cartography, Vol. 57, No 2, 2008, pp.61-79.

Kadaj R. (2009). Obliczenia i modernizacje osnów III klasy w układzie „2000” z uwzględnieniem pomiarów GPS i serwisów ASG-EUPOS. Ofic. Wyd. PRz.: Mat. III Ogólnopolskiej Konferencji N-T p.t. Kartografia Numeryczna i Informatyka Geodezyjna”, Solina, 17-19 wrzesień 2009. ISBN 978-83-7199-555-2, s. 121 143, 2009.

Kadaj R. (2010). Zastosowanie różnicowego układu obserwacyjnego typu Schreibera do opracowania sesji pomiarów statycznych GPS. Biuletyn WAT. Vol. LIX 2(658), Warszawa 2010, str. 85-106

Kadaj R. (2012a). Pół-analityczne rozwiązanie bazowe typu „float” postprocessingu GPS. Oficyna Wydawnicza Politechniki Rzeszowskiej. Zeszyty Naukowe Budownictwo i Inżynieria Środowiska 283, zeszyt 59 (nr 1/2012/II), str 169-180.

Kadaj R. (2012b). Problematyka wykorzystania serwisów postprocessingu ASGEUPOS do zakładania precyzyjnych sieci hybrydowych (zintegrowanych). II Konferencja Użytkowników ASG-EUPOS. Katowice, 20-21 listopad 2012.

Kadaj R. (2014). Algorytm opracowania modelu PL-geoid-2011. Seminarium: Realizacja osnów geodezyjnych a problemy geodynamiki KG PAN i Wydział Geodezji i Kartografii PW, Grybów, 25-27 września 2014

Kadaj R. (2015). The reference systems PL-ETRF89, PL-ETRF2000 and relation between them. In PL: Układy odniesienia PL-ETRF89, PL-ETRF2000 i relacje między nimi. Journal of Civil Engineering, Environment and Architecture, t. XXXII, z. 62 (nr 4/2015), elSSN 2300-8903,181-195

Kadaj R. (2016a). Empirical methods of reducing the observations in geodetic networks. Geodesy and Cartography. Vol. 65, No 1, 2016, pp 13-40 (in print).

Kadaj R. (2016b). The combined geodetic network adjusted on the reference ellipsoid - a comparison of three functional models for GNSS observations. Geodesy and Cartography. The work in review, April, 2016.

Kadaj R., Świętoń T. (2007). Moduł obliczeniowy (Rozdz. 5), Zastosowane algorytmy i techniki obliczeniowe (Rozdz. 6). W dokumentacji systemu: „Automatic Postprocessing Software for Trimble Application ”. Warszawa, 2007 (I ed), 2008(II ed), Rozdz. 5 i 6. GEOTRONICS sp. z o.o., TRIMBLE - POLSKA sp. z o.o. . Koordynator: GUGiK w Warszawie.

Kadaj R., Swiętoń T. (2008a). Automatic post-processing in ASG-EUPOS (in Polish: Automatyczny postprocessing w ASG-EUPOS). Geodeta, No. 10, 2008, pp. 14-18.

Kadaj R., Świętoń T. (2008b). Moduł postprocessingu GPS w systemie GEONET (poster). Współautor: T. Świętoń. Mat. Konferencji „Satelitarne metody wyznaczania pozycji we współczesnej geodezji i nawigacji", Komisja Geodezji Satelitarnej Komitetu Badań Kosmicznych i Satelitarnych PAN, WAT - Warszawa, 20-21 listopad 2008; 
Kadaj R., Świętoń T. (2009a). Postprocessing po polsku. GEODETA - MAGAZYN GEOINFORMACYJNY, dodatek NAWI 1(19) marzec 2009, ISSN 1733 - 6448, str. $32-33$.

Kadaj R., Świętoń T. (2009b). Algorytm i oprogramowanie modułu automatycznego postprocessingu w polskim systemie satelitarnych stacji referencyjnych ASGEUPOS. ZN Wydz. Bud. i Inż. Środowiska PRZ, t.262, z.51, s.37-57, 2009.

Kadaj R., Świętoń T. (2010). Moduł postprocessingu GPS w systemie GEONET (poster). Biuletyn WAT, Vol.LIX 2(658), Warszawa 2010, str 153-162.

Kadaj R., Świętoń T. (2012). Transpol 2.06 - program transformacji i przeliczeń współrzędnych pomiędzy różnymi układami w państwowym systemie odniesień przestrzennych. Opis algorytmów i programu. Wykonano na podstawie umowy BO4-2503-183/GI-2500-610-83/2012 z dnia 17 grudnia 2012. (c) GUGiK (program wraz opisem udostępniony na stronach: www.asgeupos.pl , www.gugik.gov.pl )

Kashani I., Wielgosz P., Greiner-Brzezińska D. (2003). Datum Definition in the Long Range Instantaneous RTK GPS Network Solution. Journal of Global Positioning Systems, Vol. 2, No.2, pp. 100-108.

Krakiwsky, E.,J., Thomson, D.B. (1974). Mathematical models for the combination of terrestrial and satellite Networks. The Canadian Surveyor, 28(5).

Kryński J., Kloch-Główka G., (2009). Evaluation of the Performance of the New EGM2008 Global Geopotential Model over Poland. Geoinformation Issues, Vol. 1, No $1,7-17 / 2009$

Liwosz T. , Rogowski J., Kruczyk M., Rajner M., Kurka W.(2012). Wyrównanie kontrolne obserwacji satelitarnych GNSS wykonanych na punktach ASG-EUPOS, EUREF-POL, EUVN, POLREF i osnowy I klasy wraz z ocena wyników. Katedra Geodezji i Astronomii Geodezyjnej Wydział Geodezji i Kartografii Politechnika Warszawska Warszawa, 15 grudnia 2011. Raport dla GUGiK -Warszawa.

Łyszkowicz A. (2009). Assessment of accuracy of EGM08 model over the area of Poland. Technical Sciences, No12, 2009, 118-134.

Łyszkowicz A. (2012). Geodezja fizyczna. Wyd. UW-M w Olsztynie. Olsztyn 2012.

Leick A. (2004): GPS Satellite Surveying. John Wiley \& Sonst, Inc. (Third Edition). ISBN 0-471-05930-7.

Olszak T., Piętka D., Andrasik E. (2014). Quasi-geoida-idealnie dopasowana czy idealnie grawimetryczna. Seminarium: Realizacja Osnów Geodezyjnych a Problemy Geodynamiki. Komitet Geodezji PAN. Grybów, 25-27.09.2014

Pavlis N.K., Holmes S.A., Kenyon S.C., Factor J.K., (2008). An Earth Gravitational Model to Degree 2160: EGM2008, EGU General Assembly 2008, Geophysical Research Abstracts, Vol. 10, EGU2008-A-01891.

Original informations and data: National Geospatial-Intelligence Agency, USA, http://earth-info.nga.mil/GandG/wgs84/gravitymod/egm2008/egm08_wgs84.html

Strauss R., Walter H (1993). Die Ausgleichung von GPS-Beobachtungen im System der Landeskoordinaten. AVN 6/1993, 207-212

Strehle J. (1996). Ermittlung von Landeskoordinaten aus GPS-Messungen. Mitteilungsblatt DVW-Bayern 41/1996, 623-645

Szpunar W. (1982). Fundamental of higher geodesy. In Polish: Podstawy geodezji wyższej. PPWK-Warszawa 1982.

Świątek, K. (1986). Wyrównanie łączne sieci naziemnej i doplerowskiej. Geodezja i Kartografia, XXXV, 3-4.

Świątek, K. (1988). Wyrównanie sieci geodezyjnych z wykorzystaniem pomiarów doplerowskich i analiza modeli transformacji. Acta Acad. Agricult. Ac. Technicae Olstenensis. Suplementum A. No. 17. 
Świętoń T. (2014). Optymalizacja korekt lokalnych w zadaniach transformacji pomiędzy układami kartograficznymi na przykładzie układów 1965 i 2000. Rozprawa doktorska. AGH Kraków, Wydział Geodezji Górniczej i Inżynierii Środowiska 20 marzec, 2014.

Thomson D.B. (1976). Combination of Geodetic Networks. Technical Report No. 30, April 1976, Department of Surveying Engineering University of New Brunswick, Canada

Trojanowicz M. (2009). Ocena dokładności globalnych modeli geopotencjału EGM96 i EGM08 na obszarze Dolnego Śląska. Acta Sci. Pol., Geodesia et Descriptio Terrarum 8(1) 2009, 19-30

Warchałowski E. (1952). Higher geodesy - mathematical part. In Polish: Geodezja Wyższa - część matematyczna. PWN - Warszawa 1952.

Welsch W.M., Oswald W. (1984). Kombinierte Ausgleichung von DopplerSatellitennetzen und terrestrischen Netzen. In: Schödlbauer, A., Welsch, W. (Hrsg.) : Satelliten-Doppler-Messungen Beiträge zum Geodätischen Seminar 24/25. September 1984. Schriftenreihe des Wissenschaftlichen Studiengangs Vermessungswesen der Hochschule der Bundeswehr München, Heft 15, S. 155191 ISSN: 0173-1009

Yang M., Goad C., Schaffrin B. (1994). Real-time on-the-fly ambiguity resolution over short baseline in the presence of anti-spoofing. Proceedings of ION GPS-94, Salt Lake City, p. 519

\section{Authors:}

prof. dr hab. inż. Roman Kadaj ${ }^{1)}$, geonet@geonet.net.pl

dr inż. Tomasz Świętoń ${ }^{1)}$, swieton@prz.edu.pl

1) Department of Geodesy and Geotechnics,

Faculty of Civil and Environmental Engineering and Architecture,

Rzeszow University of Technology 